\title{
The Role of Social Capital on Cocreating Value for Social Enterprises: The Service Dominant Logic Perspective
}

\author{
Nila Armelia Windasari \\ National Tsing Hua University, \\ Taiwan \\ nila.armelia@iss.nthu.edu.tw
}

\author{
Fu-ren Lin \\ National Tsing Hua University, \\ Taiwan \\ frlin@mx.nthu.edu.tw
}

\author{
Hungwei Chen \\ Natinoal Tsing Hua University, \\ Taiwan \\ hungwei.chen@iss.nthu.edu.tw
}

\begin{abstract}
The definition of a social enterprise makes it distinctive as a form of organizational hybrid. For a social enterprise, which goal is to create social value which benefits its stakeholders, it is important to highlight the process of value co-creation through interaction and integration of resources within and among service systems rather than merely measuring tangible outcomes. Value created on a social enterprise emphasizes the importance of sharing benefits among its stakeholders. This research aims to examine how social capital creates value for a social enterprise's stakeholders. We employed Service-Dominant Logic to define service systems, and then analyzed the role of social capital on building collaborative competence which creates value for stakeholders. In this research, we used case study approach and conducted in-depth interview of three social enterprises' key stakeholders including customers, business partners, and management. We summarize the findings to identify the factors affecting value creation for social enterprises.
\end{abstract}

\section{Introduction}

The term social enterprise emerged in research within latest ten years, as no articles on social enterprise appeared on the seven top-ranked academic business and management journals before 2006 [1]. Several scholars mentioned social enterprise as a new entity, one of the forms of third-sector organizations [2] that has been growing significantly in several regions in the world in terms of exact scale and contributions to economies and societies worldwide [3].

Social enterprise is a form of organisational hybrid, which applies the methods used in the private sector to achieve primarily social aims. There are trends and tendencies on social enterprise innovation to manage the resources collectively within stakeholders and increase public independencies to solve social problems [4], create social value rather than personal wealth for capitalists [5]. By this explanation, it is important to underline value cocreation with involved stakeholders as an inseparable part of the abilities and efforts of a social enterprise to manage the resources internally and externally.

Value is an abstract term commonly used nowadays to describe the assessment of outcomes usually perceived by different actors in the value creation ecosystem. Value is usually operationalized and measured by tangible outputs, such as products and market share [6]. Some of research in social enterprises measured value using SROI (Social Return on Investment) by calculating the value of social benefit using the traditional approach of NPV determined by company itself $[7,8]$. In the other hand, the primary goal of a social enterprise is to create the social value to benefit all constituent stakeholders. It is critical to highlight the process of value cocreation through interaction and integration of resources within and among social enterprises ecosystem. Therefore, we argue that examining value for social enterprise is more appropriate to be seen from the cocreation process rather than measuring the tangible forms of the output, since value is created during the process of resource exchange among stakeholders.

By taking Service-Dominant Logic (S-DL), value is resulted from the beneficial application of operant resources, which are sometimes transmitted through operand resources or goods [9]. Operant resources include knowledge and skills of actors, which could be individuals or organizations inhabited in the ecosystems. Thus, our argument is in line with S-DL view that value is created collaboratively through the combined efforts of the social enterprise, employees, customers, business partners, and other entities related to given exchanges, but is always determined by the beneficiary [10]. Combined efforts appraise the importance of active collaborations between all stakeholders in value networks.

This research aims to answer the questions on how social capital promotes value cocreation process within social enterprise's stakeholders. We argue that social capital is the essential factors in value creation for 
social enterprises. Because of mixed resource structure characteristics of social enterprises, taking the perspective of social capital can better understand the multiple goals and tentative effects of social enterprises [11].

This study extends Tsai and Ghoshal's framework of social capital dimensions [6] and takes the lens of S-DL to examine value cocreation process in social enterprises. We rarely found that social enterprise research linked with value cocreation using S-DL. We explain the abstract view of S-DL perspective on social capital role in value cocreation for social enterprises in Table 1.

Table 1. Theoretical foundation of value cocreation based on social capital, social enterprise, and S-DL

\begin{tabular}{|c|c|c|}
\hline \multicolumn{2}{|c|}{ Theoretical Foundations } & $\begin{array}{l}\text { Cocreating } \\
\text { Value for } \\
\text { Social } \\
\text { Enterprise }\end{array}$ \\
\hline $\begin{array}{l}\text { Social } \\
\text { Enterprise }\end{array}$ & $\begin{array}{l}\text { Manage the resources } \\
\text { collectively within } \\
\text { stakeholders and increase } \\
\text { public independencies to } \\
\text { solve social problems }\end{array}$ & \multirow{3}{*}{$\begin{array}{l}\text { Social } \\
\text { capital as } \\
\text { the resource } \\
\text { enables } \\
\text { actors in the } \\
\text { social } \\
\text { enterprise } \\
\text { ecosystem } \\
\text { to } \\
\text { collaborate } \\
\text { and } \\
\text { cocreate } \\
\text { value }\end{array}$} \\
\hline $\begin{array}{l}\text { Social } \\
\text { Capital }\end{array}$ & $\begin{array}{l}\text { Individuals engaged in } \\
\text { interactions and networking } \\
\text { as embedded resources in } \\
\text { social network }\end{array}$ & \\
\hline $\begin{array}{l}\text { Service- } \\
\text { Dominant } \\
\text { Logic }\end{array}$ & $\begin{array}{l}\text { Value is cocreated by } \\
\text { integrating resources from } \\
\text { multiple actors in the service } \\
\text { ecosystem, but is always } \\
\text { determined by the } \\
\text { beneficiary. } \\
\text { Value is resulted from the } \\
\text { beneficial application of } \\
\text { operant resources }\end{array}$ & \\
\hline
\end{tabular}

This research attempts to fill in the gap by using various dimensions of social capital to measure the effects of operant resources in value cocreation. We anticipate this research to propose a parsimonious model based on the S-DL to form the framework, from 'social capital' as operant resource and 'value created' as the outcome. The result is expected to shed the light on the strategy of forming social enterprises to achieve their aims on social impacts. In larger application, this model is expected to be able to explain how different key stakeholders cocreate value within business ecosystem by enabling its social capital.

\section{Theoretical foundations}

This research utilizes social capital as the underlying theory to understand how stakeholders cocreate value. Previous research on social capital determined value based on definite variables which are easily traceable, such as number of product generated [6]. Since it was taken in business settings, the organization structure is more vivid, and profit-oriented company has accessible resource to do so. While in social enterprise context, they attempted to calculate the social value according to its return of investment on social benefit called SROI [7, 8]. However, both approaches identify the value only determined by the standpoint of one-sided company and neglected the role of other actors in the value creation process.

Other conceptual works using social capital in social enterprise context were accomplished in generating theoretical model for collaborative network [12]. However, the model did not explain how the relationships in the collaborative networks were able to contribute further to organizational value creation. Although some scholars identified social value creation in social enterprise by linking it with stakeholder participation and persuasion [13], it is still hard to find the research assessing the value created in corresponding involved stakeholders.

\subsection{Value in social enterprises}

Many papers defining social enterprise avoided using clear criteria but rather used a set of organizational forms and activities as a way of defining social enterprises (SEs) [14]. SEs are distinguished from other organizations by the simultaneous possession of two attributes: SEs trade goods and/or services in a market (so they are a type of business entity and not simply a voluntary or community organization) and the primacy of social aims [15]. There are two dimensions inherent of this definition to define a social enterprise; economic and entrepreneurial dimension, and social dimension. Social enterprise concerns the use of business means to pursue social ends and the interaction between these two dimensions that underpins unique boundaries of social enterprise research.

From the aforementioned definitions, we understand that value in social enterprise highly correlates with stakeholders' value. Stakeholders comprise people and organizations both inside and outside to receive and create value from organizational actions. Social enterprises are driven by providing social value and improving social wellbeing by conducting commercial business. Contributions and benefits are common terms describing the value created. It pays more attention to the impact on all stakeholders and benefit shared to all parties involved with the enterprise. 
To achieve SE's sustainability, social entrepreneurs must develop their business and manage resources with a commercial as well as a social remit [16]. Social enterprises have to seek sustainable resources utilized from their business networks. In order to meet their social aims, SEs have to work together with their beneficiary and integrate resources with them. So that the value they proposed will be congruent with the value perceived by beneficiaries.

Value in social enterprise is usually translated as social value. In truth, with a hybrid view of social benefits and individual business profit, the nature of investment and return are not a tradeoff between social and financial interest but rather the pursuit of an embedded value proposition composed of both [17]. Therefore, the value we examine in this research encompasses stakeholders' value which is the combination of both social and business values.

\subsection{Social capital}

Social capital has been explored in multidisciplinary research. The premise behind the notion of social capital is simple and straightforward: investment in social relations with expected returns [18]. The neo-capital theories in social capital are mainly from three authors: Bourdieu, Coleman, and Putnam [19-21], in which three agreed that individuals engaged in interactions and networking as embedded resources in social network will enhance the outcomes of actions.

Social capital theory is commonly used by either individual or group level of analysis. In organizational research, it often refers to the norms and networks that enable people to act collectively. Several researches defined social capital as resources. The capability of collective action among the group of people is an important asset for organizations. Another notions embedded with social enterprise are "relationship within the networks" and "common objectives". Besides the character of mixed resource structure in social enterprises [11], these notions prove that social capital perspective is appropriate to understand the value creation process in social enterprise.

This study emphasizes social capital in organizational settings; that is how individuals within social enterprise represent as a group of people or stakeholders. Nahapiet and Ghoshal first attempted to conceptualize and establish the theoretical model of social capital within organizational settings [23]. As taking the notions that SEs are relationships within networks and common objectives, social capital possesses many attributes. It categorized into three clusters of attributes: structural, relational, and cognitive dimensions $[6,22,23]$. As presented in Table
2 , three dimensions of social capital are manifested in various extensions and combinations of different facets, with subject mostly applied to profit-oriented sectors.

1. Structural capital is the extent to actors which are connected [24]. It essentially defines the potentials or possibilities for nascent entrepreneurs' capacity to access information, resources, and support [23]. Strong social interactions and ties are beneficial and productive resources for enterprises. Frequent and close social interactions permit actors to know one another, share important information, and create common points of view [6].

2. Relational dimension concerns the kinds of personal relationships people have developed through a series of interactions [25]. It focuses on the quality of actors' connections and particular relationships people have established, such as respect, trust, trustfulness, and friendliness.

3. Cognitive dimension specifies resources that provide "shared representations, interpretations and systems of meaning among parties." Cognitive dimension implies a paradigm that facilitates common perspectives and understandings of collective goals [24], and proper ways of acting in social systems [26]. Several studies translated cognitive dimension to such constructs as shared norms, goals, and languages.

From the aforementioned explanation about the three dimensions of social capital, we select important keywords as the elements to represent each dimension listed in Table 2. These elements will be further used in our analysis for pattern matching and for building logic model in order to analyze our interview data.

Table 2. Elements of three social capital constructs

\begin{tabular}{|l|l|}
\hline \multicolumn{1}{|c|}{$\begin{array}{c}\text { Dimensions on Social } \\
\text { Capital }\end{array}$} & \multicolumn{1}{c|}{ Elements } \\
\hline $\begin{array}{l}\text { Structural } \\
\text { (extent of connections) }\end{array}$ & $\begin{array}{l}\text { Shared resources, frequent } \\
\text { interaction, social interaction }\end{array}$ \\
\hline $\begin{array}{l}\text { Relational } \\
\text { (quality of relationship) }\end{array}$ & $\begin{array}{l}\text { Respect, trust, trustfulness, } \\
\text { and friendliness }\end{array}$ \\
\hline $\begin{array}{l}\text { Cognitive } \\
\text { (common perspectives) }\end{array}$ & $\begin{array}{l}\text { Shared view, common } \\
\text { perspective }\end{array}$ \\
\hline
\end{tabular}

Social capital is "convertible"; that its various forms can be "converted" to other kinds of capital [19]. No one player has exclusive rights of ownership to it. If you or your partner in a relationship withdraws (structural), the connection dissolves with whatever social capital (relational) it contained. Structural capital is the most basic form of social capital and the origin for the emergence of relational and cognitive capital. Without physical centrality or networks (structural capital), entrepreneurs would be less likely to develop trustful relationships (relational capital), subsequently hampering the formation of shared norms 
and values in supporting venture creation (cognitive capital) [27].

Three dimensions and the several facets of social capital highlighted by researchers are likely to be interrelated in complex ways. It implies that various dimensions of social capital are not mutually exclusive but interconnected. Our primary focus is to understand the interdependent effects of these constructs on the collaborative competence.

\subsection{Service-Dominant Logic (S-DL)}

Service-Dominant Logic (S-DL) emphasizes the central point of value cocreation. Using service system view, S-DL claims that value is cocreated by integrating resources from multiple actors in the service ecosystem. S-DL provides an alternative perspective in viewing the value and how value is cocreated [10]. This view appreciates the collaboration of actors within and among service systems. While putting into the social enterprise context, S-DL relatively fits in explaining how stakeholders communicate in value networks of social enterprises.

Table 3. Foundation premises (FPs) of S-DL and the implications to social enterprise activities

\begin{tabular}{|l|l|l|}
\hline \multicolumn{2}{|l|}{$\begin{array}{l}\text { FPs related to value } \\
\text { creation }\end{array}$} & Implication to social enterprises \\
\hline 1 & $\begin{array}{l}\text { Service is the } \\
\text { fundamental basis } \\
\text { of exchange }\end{array}$ & $\begin{array}{l}\text { The main activity of a social } \\
\text { enterprise is to provide service } \\
\text { (align with their objectives). }\end{array}$ \\
\hline $\begin{array}{l}\text { FP } \\
3\end{array}$ & $\begin{array}{l}\text { Goods are a } \\
\text { distribution } \\
\text { mechanism for } \\
\text { service provision }\end{array}$ & $\begin{array}{l}\text { Goods provided (or produced) in } \\
\text { social enterprises act as the } \\
\text { transmitter of service for users }\end{array}$ \\
\hline $\begin{array}{l}\text { FP } \\
6\end{array}$ & $\begin{array}{l}\text { Value is cocreated } \\
\text { by multiple } \\
\text { actors, always } \\
\text { including the } \\
\text { beneficiary }\end{array}$ & $\begin{array}{l}\text { Value created in social enterprise is } \\
\text { not merely produce by the } \\
\text { organization, but that is the result of } \\
\text { the collaboration of stakeholders } \\
\text { involved, such as: management, } \\
\text { business partners, and customers } \\
\text { acting as the beneficiary. }\end{array}$ \\
\hline $\begin{array}{l}\text { FP } \\
7\end{array}$ & $\begin{array}{l}\text { Actors cannot } \\
\text { deliver value but } \\
\text { can participate in } \\
\text { the creation and } \\
\text { offering of value } \\
\text { propositions }\end{array}$ & $\begin{array}{l}\text { A social enterprise serves as service } \\
\text { offeror, which promotes the value } \\
\text { propositions to the public or those } \\
\text { who need it by involving them in } \\
\text { the service process. }\end{array}$ \\
\hline $\begin{array}{l}\text { FP } \\
9\end{array}$ & $\begin{array}{l}\text { All social and } \\
\text { economics actors } \\
\text { are resource } \\
\text { integrators }\end{array}$ & $\begin{array}{l}\text { A social enterprise collaborates with } \\
\text { many different parties which own } \\
\text { various resources. They integrate } \\
\text { the resources to achieve common } \\
\text { goals within the service system. }\end{array}$ \\
\hline $\begin{array}{l}\text { FP } \\
10\end{array}$ & $\begin{array}{l}\text { Value is always } \\
\text { uniquely and } \\
\text { phenomenological } \\
\text { ly determined by } \\
\text { the beneficiary }\end{array}$ & $\begin{array}{l}\text { Customer in certain social context } \\
\text { are those who experience service } \\
\text { offerings and able to determine the } \\
\text { value through interaction with the } \\
\text { social enterprise }\end{array}$ \\
\hline
\end{tabular}

S-DL consists of several foundation premises (FPs), and there are six FPs related to value cocreation [28]. Although there are several rounds of modification for FPs, these FPs used in this research are the latest proposed FPs [29]. Based on these six FPs, we identify the implications of these premises and direct it to the context of social enterprise as listed in Table 3 .

From Table 3, relational networks of the stakeholders are embedded in the social enterprise activities taking S-DL as the point of view. This kind of relationship is presented on the way they interact and common goals they shared. S-DL further explains the mechanism of value cocreation process, as well as what kind of resources needed. In S-DL, the concept of resource is broadened to include anything an actor can draw to contribute to the value creation [9]. The most pivotal resources are operant resource, which are often dynamic and difficult to transfer. Social capital is able to create certain competences as one of the form of operant resources for social enterprise. The social structure and stakeholder relationships on the social enterprise will foster interactions and thus create the collaborative competences. By mobilizing social capital from the stakeholders via effective mechanisms, the social enterprise will be able to create social value as outcomes of its business.

\section{Case studies}

Our research objective is to understand the role of social capital in the value cocreation process of social enterprises. Given few empirical researches in value cocreation process in social enterprise and the exploratory nature of this study, the qualitative case-study approach is considered appropriate for this research. Three social enterprises were selected according to their business scopes, unique value propositions, and business models. They have different organizational sizes, numbers of employees, and breadth of activities. We also chose the cases from different industries, ranging from technology, transportation, to cultural space. By using multiple cases, it enables us to do comparison and generate more robust results [30].

In order to obtain evidential information, this study analyzes data from interviewing stakeholders (manager/CEO, employees, customers, and business partners) within the SE's service systems. Value cocreation requires the actions taken by actors in the actor networks. Therefore, we argue that all stakeholders within the ecosystem will be the subjects for interview. It is important to note that all interviewees are involved in this research on a voluntary basis. Semi-structured interviews were used to gather evidential information from interviewees. 
The semi-structured interview for each stakeholder was recorded, and consists of four to six open questions for a stakeholder. There are twelve interviews conducted in total. For each social enterprise, at least one interviewee from the organization (CEO, manager, or staffs), one business partner, and one customer were interviewed. Each interview session lasted approximately one hour to enable an interviewee to answer questions without time pressure. Two co-authors attended each interview. Three co-authors discussed the findings from the information provided by interviewees and the social capital dimensions to specify the factor affecting the value creation for social enterprises. The findings of three cases are described in the following subsections.

\subsection{Our City Love}

Our City Love (OCL) is a social enterprise providing technological services via mobile apps which provide guidance for users to access friendly-services, such as breastfeeding rooms, accessible restaurant for people in wheelchair, etc. They help service providers enhance their facilities to be able to serve physically-challenged customers, such as handicapped or aged people on wheelchairs. To broaden its influences, OCL explored its business from Taiwan to other countries in Asia.

OCL's value propositions describe what it aims to offer to different user groups. The first and basic user group is physically disabled customers. The other user groups are more generic to those who may need information to engage physically friendly services.

OCL licenses its apps to service providers, such as restaurants, telecom companies, and transportation companies to allow the disabled (or their families) to search service providers which are disabled-friendly. Further, OCL cooperates with the disabled who serve as investigators to survey service providers e.g., restaurants, to evaluate their qualification to be listed as friendly service providers on the apps.

In interviewing OCL's stakeholders, we interviewed the founder, employees, and customers recommended by the founder. We selected interviewees from the business partners which have been rated as moderate service providers (above 3.5 out of 5) listed on the apps.

\subsection{Kendama}

Kendama is a social enterprise located in the downtown of Hsinchu City aiming to improve city life via promoting local cultures. Hsinchu is known as one of the old cities in Taiwan, divided into two different regions. The eastern Hsinchu turned into the center of science and technology (Hsinchu Science Park); however, the economy of the old downtown decayed in past decades. This implies that few people access cultural heritages in Hsinchu City as workers in Science Park have limited options to enjoy their leisure time.

To facilitate in-depth and intensive interaction with the public, Kendama applied a multi-channel platform including physical and online channels to reach the public. To enrich cultural contents for people living in Hsinchu, Kendama held several cultural activities. One of them is held monthly called read-by-walk, which invites the public to beware some issues in the city by walking on the city together.

They have an on-site platform called Kendama Studio. This studio is transformed from an idled old-building, by removing broken compartments and decoration. With flexible furniture, Kendama Studio became an open space for hosting lunch activities and demonstrating cultural information. Inside the studio, bartenders serve customers and directly interact with people. It publishes "Meat Ball Soup" magazine which covers cultural issues, heritages, city characteristics and different life forms in Hsinchu, and sells it to independent bookstores. It also utilizes online channels, such as online bookstore and Facebook fans page, to build the relationship with greater public.

In order to redefine the cultural value of Hsinchu City, Kendama collaborates with different types of organizations (cultural, academic, NGOs), culture workers, cultural heritage owners to serve citizens interested in cultural engagements. It interacts with some organizations having common view in some projects. Through the interactions, they shared their business networks, human resources, and know-how from each other.

\subsection{Duofu}

Duofu is a passenger car rental and leasing company. It provides bus service with accessible equipment for people in wheelchairs (especially electronic wheelchair). Its on-demand services are available to whomever and whenever needs it (80\%-90\% is for medical care). In addition, it provides the customized travel guided service for disabled people. It also owns a store selling some assistive devices and healthy foods.

Duofu identified the need of those who are on wheelchairs for the interaction with outside world. It has been trying to create "memorable moments" for customers (passengers) by customized in-depth travel guided services. In order to achieve this goal, Duofu realizes that it should start from training its employees and frontliners (drivers). CEO tried to lowers the 
power distance by empowering employees, so they can realize that working in this social enterprise is part of their daily lives. Drivers are capable of helping passengers with special needs and entertaining customers during the trip.

\section{Value cocreation process in social enterprise (SE)}

Our first step in data analysis is to understand the social enterprise ecosystem. First question in interview is directed to understand the business models, value propositions, and main stakeholders involved in their business ecosystems. In general, the major stakeholders involved are SE management (CEO or manager), employees within the SE, business partners (profit and non-profit organizations), and customers (which sometimes including the public) as sketched in Figure 1.

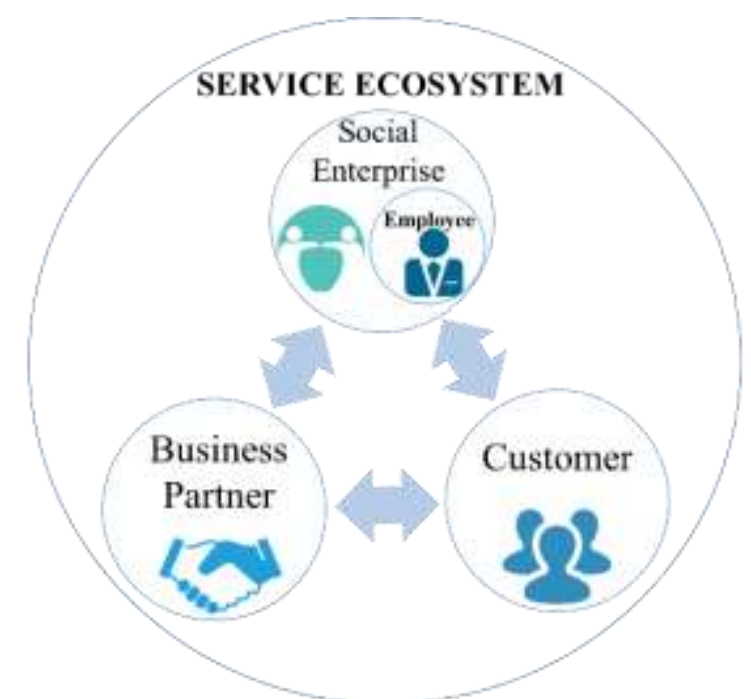

Figure 1. Cocreation between stakeholders in social enterprise ecosystems

Our second step is to analyze interview records with an open coding approach through an iterative process. Two co-authors initially coded all the data collected and validate the elements of each dimensions in social capital construct listed in Table 2 based on literature review. Then, we identified several key terms extracted from interviews of three SES to match with and summarize the interview results based on interviewees' responses. We took the major points to determine to which construct it belongs and listed in Table 4.

Finally, we compared the value proposed by SEs with the value perceived by the other stakeholders. The value propositions are triangulated from interviewing CEOs or managers, and SE's official websites.
Regarding the interview results from employees, we found that value perceived by employees are coherent with the value proposed by SEs. We can infer that the value perceived within the organization is consistent having internal consistency. Therefore, we encapsulate employees into SE management.

In structural dimension, we identified the type of channels they are using to interact (online, on-site or physical platform), intensity of their interaction, the existence of resource and information they shared. Multiple respondents described how social media ease their interactions and circulate information within their networks (Facebook, LINE, or fanpages). Therefore, the role of online platform is inevitable to support SEs to utilize their channels to build the structural dimension of social capital.

SEs also used their services as a platform to cocreate value with customers. OCL made use of its apps not only to recommend friendly service but also to receive information from the public. Kendama utilize their Studio, held monthly activities to introduce cultural value of Hsinchu city and interact with citizens at the same time. Duofu utilizes its service encounters with passengers during the trip to make the trip memorable for customers. This finding aligns with the FPs of S-DL [29] that the use of services is the fundamental basis of exchange, and even they use physical platforms, it acts as transmitter of their service.

In relational dimension, social capital can be seen as relationships built by stakeholders within SE ecosystems. The relational dimension was expressed by profound relationships such as friendliness, trust, and mutual respect. The relational dimension occurs often in the service encounters and resulting from intensive interactions. We can also infer that the quality in relational dimension in some extent is influenced by overall linkage between actors. This finding is in line with the concept of structural and relational embeddedness [25]. Further, the relational facets arise from human factors, interactions between peoples. Therefore, human resources (employees and frontliners) in social enterprises are very important to create and maintain relational capital with stakeholders.

From Table 4, we can infer that relational dimension mostly appears between management and customer perspectives. It can be seen from customer expression who feels the staffs of SE are very friendly ("always smile", "hangout like friends") and they trust them ("will always use their service for next trip"). It can be understood that social enterprise pays attention to customers as their main beneficiary. 
Table 4. Summary of interviews with related key terms on Social Capital

\begin{tabular}{|c|c|c|c|c|}
\hline Dimension & Construct & Management & Customer & Partner \\
\hline \multirow[t]{5}{*}{ Structural } & \multirow[t]{2}{*}{$\begin{array}{l}\text { Shared resource } \\
\text { (and } \\
\text { information) }\end{array}$} & \multirow{2}{*}{$\begin{array}{l}\text { Friendly-surveyor will come to } \\
\text { the service provider's place and } \\
\text { do survey, they will upload all } \\
\text { the information needed (ramp } \\
\text { tilt, availability of disabled } \\
\text { facilities, etc) through the APPs } \\
\text { and stored on the cloud. (OCL) }\end{array}$} & $\begin{array}{l}\text { If it sounds interested, I am } \\
\text { willing to spread information } \\
\text { about their events to my friends } \\
\text { (Kendama) }\end{array}$ & \multirow{2}{*}{$\begin{array}{l}\text { We create joint-flyer } \\
\text { containing our monthly event } \\
\text { to be put in their studio and } \\
\text { our space....our members also } \\
\text { help spreading it out to } \\
\text { friends and networks } \\
\text { (Kendama) }\end{array}$} \\
\hline & & & $\begin{array}{l}\text { After I finished surveying, I will } \\
\text { share the information about the } \\
\text { restaurant to my friends, and if } \\
\text { there are inappropriate service } \\
\text { they will report back) (OCL) }\end{array}$ & \\
\hline & $\begin{array}{l}\text { Intensity of } \\
\text { interaction }\end{array}$ & $\begin{array}{l}\text { "We held monthly "read by } \\
\text { walk" stroll around several } \\
\text { places in the city" (Kendama) }\end{array}$ & $\begin{array}{l}\text { I visit Kendama studio around } 5 \\
\text { times (Kendama) }\end{array}$ & $\begin{array}{l}\text { We almost never maintain any } \\
\text { communication with } O C L . \\
\text { Only some of the surveyor } \\
\text { came here for eat. }(O C L)^{*}\end{array}$ \\
\hline & \multirow[t]{2}{*}{$\begin{array}{l}\text { Communication } \\
\text { channel }\end{array}$} & $\begin{array}{l}\text { We held several cultural } \\
\text { activities, build Studio to } \\
\text { interact directly with customer, } \\
\text { publish Meat Ball Soup } \\
\text { magazine (Kendama) }\end{array}$ & $\begin{array}{l}\text { For young people like us, we } \\
\text { usually know the information } \\
\text { through their fanpage } \\
\text { (Kendama) }\end{array}$ & \multirow{2}{*}{$\begin{array}{l}\text { Each time before Duo Fu held } \\
\text { a trip, their staff will contact } \\
\text { us by phone and facebook to } \\
\text { reserve meal and check detail } \\
\text { schedule. During the trip, both } \\
\text { of our staffs serve customers } \\
\text { together. (Duo Fu) }\end{array}$} \\
\hline & & $\begin{array}{l}\text { In relationship with customer, } \\
\text { drivers build extremely close } \\
\text { personal relationship with them } \\
\text { by social media (LINE) (Duofu) }\end{array}$ & $\begin{array}{l}\text { I know OCL from Facebook and } \\
\text { I shared to pages to my friendlist } \\
(\text { OCL })\end{array}$ & \\
\hline \multirow[t]{5}{*}{ Relational } & \multirow[t]{3}{*}{ Friendly } & \multirow{2}{*}{$\begin{array}{l}\text { We have Bartender who serve } \\
\text { customer and have direct } \\
\text { interaction with people who } \\
\text { experience the studio } \\
\text { (Kendama) }\end{array}$} & $\begin{array}{l}\text { Later we become like friend, } \\
\text { hangout together, sometimes } \\
\text { visit each other (Kendama) }\end{array}$ & \multirow[b]{3}{*}{ - } \\
\hline & & & \multirow{2}{*}{$\begin{array}{l}\text { The driver always smile, never } \\
\text { shown tiredness even after } \\
\text { driving long hours and help us } \\
\text { carrying very heavy wheelchair } \\
(\text { Duo Fu) }\end{array}$} & \\
\hline & & $\begin{array}{l}\text { We are trying to create } \\
\text { "memorable moments" for } \\
\text { passengers by customized } \\
\text { in-depth travel guide service. } \\
\text { Even customers have their own } \\
\text { "fans" (favorite driver) (Duofu) }\end{array}$ & & \\
\hline & $\begin{array}{l}\text { Trust and } \\
\text { trustworthiness }\end{array}$ & $\begin{array}{l}\text { Customer told us they just have } \\
\text { limited budget (to pay for the } \\
\text { service), but they are really in } \\
\text { need. So we decide to tell them } \\
\text { the price is enough, and } \\
\text { charged with ourselves to the } \\
\text { loss (Duofu) }\end{array}$ & $\begin{array}{l}\text { I will always use Duo Fu for my } \\
\text { next trip }(D \text { (Do } F u)\end{array}$ & $\begin{array}{l}\text { I didn't thing they will make } \\
\text { benefit from us, we just } \\
\text { cooperate and benefit each } \\
\text { other (Kendama) }\end{array}$ \\
\hline & Respect & $\begin{array}{l}\text { The one who really know the } \\
\text { needs of disabled are the } \\
\text { disabled themselves, so we } \\
\text { cooperate with them to survey } \\
\text { and called them "laoshi" } \\
\text { (teacher) (OCL) }\end{array}$ & $\begin{array}{l}\text { One of drivers had received the } \\
\text { request from fan's (passangers) } \\
\text { family. They ask him to drive the } \\
\text { hearse on the fan's funeral, } \\
\text { because the fan see him as a } \\
\text { family member. (Duo Fu) }\end{array}$ & - \\
\hline \multirow[t]{2}{*}{ Cognitive } & Common view & $\begin{array}{l}\text { The true and most value is } \\
\text { "sociological imagination: flip } \\
\text { the social status and stereotypes } \\
\text { of disabled" (OCL) }\end{array}$ & $\begin{array}{l}\text { We (disabled) need everyone's } \\
\text { support, and friendly facility will } \\
\text { bring long-term impact to the } \\
\text { city }(O C L)\end{array}$ & $\begin{array}{l}\text { We don't think we have } \\
\text { similar values. At first, OCL } \\
\text { asked us to serve group of } \\
\text { people and they rated us in the } \\
\text { APPs. We will help the } \\
\text { disabled but we don't think we } \\
\text { have similar value (OCL) }\end{array}$ \\
\hline & $\begin{array}{l}\text { Common } \\
\text { interest }\end{array}$ & $\begin{array}{l}\text { Accessibility as crucial issues in } \\
\text { urban area, particularly aging } \\
\text { population, social inequality. } \\
\text { Can we make the city 100\% } \\
\text { accessible to all different } \\
\text { citizens? (OCL) }\end{array}$ & $\begin{array}{l}\text { We may pay attention into some } \\
\text { places we live nearby and give } \\
\text { us additional insights so we can } \\
\text { tell friends or people (Kendama) }\end{array}$ & $\begin{array}{l}\text { We have the common concern } \\
\text { about the development of } \\
\text { Hsinchu City, and both of us } \\
\text { want to empower local } \\
\text { community (Kendama) }\end{array}$ \\
\hline
\end{tabular}


Business partners are treated more likely as parties who also benefit customers and solve social problems. Structural and cognitive factors between social enterprises and business partners are treated under the professional compromise for business purpose. We can refer the response from Duofu business partners as below:

"Each time before Duofu held a trip, its staff will contact us by phone and Facebook to reserve meals and check detailed schedule. During the trip, both of our staffs serve customers together. But the communication is stopped after the visit ended"

Therefore, it affects the extent of their relationships. It can be inferred from the absence of business partners' responses which did not express any terms related to the quality of relationships.

Finally, in cognitive dimension, we captured several responses related to common views and interests shared by stakeholders. It came from the social issues, so that it was able to bet every stakeholder to pay attention to them. However, this vocabulary did not appear on interviews with Duofu and their constituent stakeholders, even in which prior studies revealed that cognitive dimension is normative and should exist in the behavior [23].

In several prior literatures, structural and cognitive dimensions are major antecedences. Relational dimension is the most likely influenced by the existence of the other two dimensions [6, 23]. In our OCL cases, they did not share common views and had very limited interactions. Later on, we did not find any expressions regarding profound relationship during the interviews. This notion is strengthened by our findings taken from the cases of OCL's business partner:

"We don't think we have similar value" (cognitive)
"We almost never maintain any communication with OCL" (structural)

Given no shared view and interests (cognitive dimension) and no intensive mechanisms for collaboration (structural dimension), it is hard to reach deep relationships (relational dimension).

Last stage, we attempt to do value matching from value proposed by SEs with value perceived by customer and partner. From Table 5, we can infer that not all of the value proposed is perceived equally. However, we notice that the customers and business partners as beneficiaries can determine some extent of value proposed by social enterprises. This finding is in line with S-DL FPs that beneficiaries describe the value by improvements, problems solved, several benefits and contributions they perceived.

There are several interesting findings between the role of cognitive dimension and how it relates to value perceived. First, in the case of Duofu, given that no cognitive dimension factors expressed by all stakeholders in the interview, there is still several value perceived in a certain level by customers.

"Now we can go anywhere which seems impossible before"

When we looked in-depth further, Duofu and other customers interacted well in terms of quantity (structural) and quality (relational), such as "maintain personal relationship through LINE".

Second, the case of OCL shows that not all beneficiaries are able to perceive value proposed by SEs which we mark them in asterisk. For unmatched value with partners, we can draw it back from the analysis in social capital dimensions. In the interview results in cognitive dimension, actors do not share common view. Further, they neither collaborated intensively nor enabled partners to have collaborative mechanisms.

Table 5. Comparison of value proposed by social enterprise and value perceived by beneficiaries

\begin{tabular}{|l|l|l|l|}
\hline $\begin{array}{l}\text { Social } \\
\text { enterprise }\end{array}$ & \multicolumn{1}{|c|}{ Value proposed } & \multicolumn{1}{|c|}{ Calue perceived } \\
\cline { 3 - 4 } $\begin{array}{l}\text { Our City } \\
\text { Love }\end{array}$ & $\begin{array}{l}\text { Using technology to fulfil the needs of disabled. } \\
\text { Improve the social status of the disabled with social } \\
\text { movement by encouraging social participation and } \\
\text { expanding unique job opportunities. }\end{array}$ & $\begin{array}{l}\text { We feel more } \\
\text { energetic, happy, and } \\
\text { increase our self } \\
\text { confidence }\end{array}$ & $\begin{array}{l}\text { We don't think we have significant } \\
\text { improvement after cooperating with } \\
\text { them* }\end{array}$ \\
\hline Kendama & $\begin{array}{l}\text { Enrich cultural contents for Hsinchu residences (to } \\
\text { understand Hsinchu city easily by redefining its } \\
\text { cultural value) }\end{array}$ & $\begin{array}{l}\text { We pay attention to the } \\
\text { places nearby where } \\
\text { we live } \\
\text { Sometimes it give us } \\
\text { new knowledge so we } \\
\text { can tell family and } \\
\text { friends. }\end{array}$ & $\begin{array}{l}\text { We have the common interest in } \\
\text { developing Hsinchu City, and both of us } \\
\text { want to empower local community. } \\
\text { Kendama ever started their } \\
\text { monthly-walk from our space, it helped } \\
\text { us introduce our space and bring more } \\
\text { customers. }\end{array}$ \\
\hline Duofu & $\begin{array}{l}\text { Connect accessible environment around with } \\
\text { one-demand transportation service. } \\
\text { Create new life circle of the disabled and improve } \\
\text { the confidence of the disabled during trips. } \\
\text { anywhere (which is } \\
\text { impossible before, } \\
\text { such as hiking) }\end{array}$ & $\begin{array}{l}\text { The cooperation crates an opportunity } \\
\text { to attach disabled customers. By } \\
\text { interacting with disabled customers, we } \\
\text { now have more customer groups, } \text { not } \\
\text { only disabled but also elderly }\end{array}$ \\
\hline
\end{tabular}




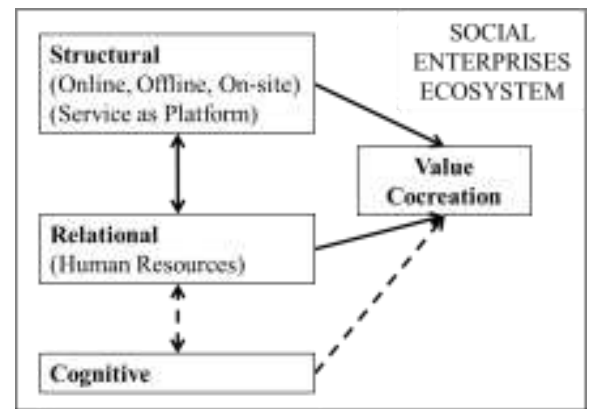

Figure 2. Relationships between social capital dimension and value cocreation in social enterprises

When we examine further, on one hand, the platform utilized by SE (apps) only allows customers and friendly ambassadors to give feedbacks, while there are no mechanisms to facilitate service providers to work together with SEs. On the other hand, OCL has the strong cognitive dimension shared with its customers to create friendly facilities to the city. Thus, it can generate better value matching that makes customer feel more energetic and happy.

Therefore, we can infer that the role of cognitive dimension plays unique aspect in reaching common goals of all stakeholders. Cognitive factors can be translated differently by different stakeholders, which depends on how SEs signal their value propositions. Cognitive capital should embody in the shared visions and collective goals of organizational partners [26]. Thus, it is important to set shared value and vision which can accommodate the concerns of all stakeholders. Hence, cognitive factors should also be supported by structural and relational dimensions to reach stronger value congruence in the ecosystem.

Our findings explain that the structural and cognitive dimensions are supported to enable value creation through the relational dimension, while the three dimensions are correlating each other. It is consistent with S-DL that actors in an ecosystem are resource integrators that they interact with each other and co-create value. The relationships between structural, relational, and cognitive dimensions towards value cocreation are sketched in Figure 2. In case studies, we found that successful value creation between stakeholders in social enterprises are supported through good relational competence that enables collaboration between actors. In contrast, when the relational dimension is absent, the value proposed by a social enterprise will be minimized determined by the beneficiary. It is proven by the statement from one of friendly restaurant rated on OCL's apps:

"We don't think we have significant improvement after cooperating with them"

\section{Discussion and conclusion}

This paper tried to understand how social capital in different dimensions influences value cocreation processes, particularly people within a social enterprise, between a social enterprise and business partners, and also between a social enterprise and customers.

The analysis shows that social enterprises nowadays utilize multichannel platforms to reach and interact with their stakeholders. Online channel is a mandatory and powerful platform to enable resource liquefaction. It enables resource sharing faster through networks of stakeholders. Further, SEs also used service as a platform which is effective to attain its social aims and interact with the public concurrently. The results also imply that relational capital (that are embedded in human resources owned by social enterprises) are important to support value cocreation. The value perceived by the beneficiary might not reflect the overall value proposed by an SE. It could vary in some extent depending on how SEs interact with their beneficiaries. The data collected allow us to identify the SEs which maintain structural social capital and show deep relational interactions are most likely meet the value proposed.

In order to meet the common value perceived, shared and collective goals in cognitive dimension should be able to accommodate the interest of all stakeholders. In the absence of cognitive dimension, SEs can still meet some extent of value perceived by beneficiaries under the support of structural and relational dimensions. However, to understand how much the influence of cognitive dimension should be tested empirically.

The findings have several implications to the value cocreation practice. First, in the process of value cocreation, social enterprises have to maintain their communication platform and human resources as pivotal resources. SEs could explore their key activities and services which enable direct interaction, not only with customers but also engaging the business partners. Hence, the relationships with partners can be enhanced beyond business matters. In the other words, our findings suggest that social enterprises have to build strong structural factors (utilizing their communication channels and services) and support relationships (using their human resources) between stakeholders to enable value cocreation. The second implication suggests social enterprise better formulate shared vision and goals which can accommodate all stakeholders' interest. Furthermore, SEs have to signal their value proposition equally to all stakeholders to reach collective goals. 
Although the findings are encouraging and useful, the present study has certain limitations. We only interviewed three social enterprises and their constituent stakeholders to capture the phenomena of value creation. However, further studies can consider the role of competitors as other actors who take place in value creation of the SE. Future development of the research should also be able to operationalize constructs proposed on the framework and empirically tested the relationship. Further study is also possible to measure in what extent value can be cocreated involving all actors within the business ecosystem.

\section{References}

[1] G. Desa, "Social entrepreneurship: snapshots of a research field in emergence," in Values and opportunities in social entrepreneurship, ed: Springer, 2010, pp. 6-28.

[2] C. Borzaga and J. Defourny, The emergence of social enterprise vol. 4: Psychology Press, 2004.

[3] K. Peattie and A. Morley, "Eight paradoxes of the social enterprise research agenda," Social Enterprise Journal, vol. 4, pp. 91-107, 2008.

[4] A. Westall, How Can Innovation in Social Enterprise be Understood, Encouraged and Enabled. London: Office of the Third Sector, 2007.

[5] E. Chell, "Social enterprise and entrepreneurship towards a convergent theory of the entrepreneurial process," International Small Business Journal, vol. 25, pp. 5-26, 2007.

[6] W. Tsai and S. Ghoshal, "Social capital and value creation: The role of intrafirm networks," Academy of management Journal, vol. 41, pp. 464-476, 1998.

[7] P. W. Ryan and I. Lyne, "Social enterprise and the measurement of social value: methodological issues with the calculation and application of the social return on investment," Education, Knowledge \& Economy, vol. 2, pp. 223-237, 2008.

[8] N. Rotheroe and A. Richards, "Social return on investment and social enterprise: transparent accountability for sustainable development," Social Enterprise Journal, vol. 3, pp. 31-48, 2007.

[9] S. L. Vargo and R. F. Lusch, "Evolving to a new dominant logic for marketing," Journal of marketing, vol. 68, pp. 1-17, 2004.

[10] S. L. Vargo, P. P. Maglio, and M. A. Akaka, "On value and value co-creation: A service systems and service logic perspective," European management journal, vol. 26, pp. 145-152, 2008.

[11] E. Adalbert, "The significance of social capital in the multiple goal and resource structure of social enterprises," in The Emergence of Social Enterprise, ed: Routledge, 2001.

[12] J. Macke, R. V. Vallejos, and J. A. R. Sarate, "Collaborative network governance: understanding social capital dimensions," in Collaborative
Technologies and Systems, 2009. CTS'09. International Symposium on, 2009, pp. 163-171.

[13] M. Di Domenico, H. Haugh, and P. Tracey, "Social bricolage: Theorizing social value creation in social enterprises," Entrepreneurship Theory and Practice, vol. 34, pp. 681-703, 2010.

[14] F. Lyon and L. Sepulveda, "Mapping social enterprises: past approaches, challenges and future directions," Social Enterprise Journal, vol. 5, pp. 83-94, 2009.

[15] K. Peattie and A. S. Morley, "Social enterprises: diversity and dynamics, contexts and contributions," 2008.

[16] B. Hynes, "Growing the social enterprise-issues and challenges," Social Enterprise Journal, vol. 5, pp. 114-125, 2009.

[17] J. Emerson, "The blended value proposition: Integrating social and financial returns," California Management Review, vol. 45, pp. 35-51, 2003.

[18] N. Lin, "Building a network theory of social capital," Connections, vol. 22, pp. 28-51, 1999.

[19] P. Bourdieu, "The forms of capital," in Handbook of theory and research for the sociology of education, J. G. Richardson, Ed., ed New York: Greenwood, 1986, pp. 241-258.

[20] J. S. Coleman, "Social capital in the creation of human capital," American Journal of Sociology, pp. S95-S120, 1988.

[21] R. D. Putnam, "The prosperous community," The american prospect, vol. 4, pp. 35-42, 1993.

[22] A. R. Anderson and S. L. Jack, "The articulation of social capital in entrepreneurial networks: a glue or a lubricant?," Entrepreneurship \& Regional Development, vol. 14, pp. 193-210, 2002/07/01 2002.

[23] J. Liao and H. Welsch, "Roles of social capital in venture creation: Key dimensions and research Implications*," Journal of Small Business Management, vol. 43, pp. 345-362, 2005.

[24] A. C. Inkpen and E. W. K. Tsang, "Social capital, networks, and knowledge transfer," The Academy of Management Review, vol. 30, pp. 146-165, 2005.

[25] M. Granovetter, Problems of Explanation in Economic Sociology. Boston: Harvard Business School Press, 1992.

[26] J. Nahapiet and S. Ghoshal, "Social capital, intellectual capital, and the organizational advantage," Academy of management review, vol. 23, pp. 242-266, 1998.

[27] R. S. Burt, Structural Holes. Cambridge, MA: Harvard Business Press, 1992.

[28] C. Grönroos, "Value co-creation in service logic: A critical analysis," Marketing theory, vol. 11, pp. 279-301, 2011.

[29] S. L. Vargo and R. F. Lusch, "Institutions and axioms: an extension and update of service-dominant logic," Journal of the Academy of Marketing Science, vol. 44, pp. 5-23, 2016.

[30] R. K. Yin, Case study research: Design and methods: Sage publications, 2013. 